\title{
Optimizing Fungicide Timing for the Control of Rhizoctonia Crown and Root Rot of Sugar Beet Using Soil Temperature and Plant Growth Stages
}

\author{
W. W. Kirk, P. S. Wharton, R. L. Schafer, and P. Tumbalam, Department of Plant Pathology, Michigan State Uni- \\ versity (MSU), East Lansing 48824; S. Poindexter, Saginaw County Extension (MSU), Saginaw, MI 48607; \\ C. Guza, R. Fogg, T. Schlatter, J. Stewart, and L. Hubbell, Michigan Sugar Company, Bay City, MI 48706; and \\ D. Ruppal, Syngenta Seeds/Hilleshog
}

\begin{abstract}
Kirk, W. W., Wharton, P. S., Schafer, R. L., Tumbalam, P., Poindexter, S., Guza, C., Fogg, R., Schlatter, T., Stewart, J., Hubbell, L., and Ruppal, D. 2008. Optimizing fungicide timing for the control of Rhizoctonia crown and root rot of sugar beet using soil temperature and plant growth stages. Plant Dis. 92:1091-1098.

Azoxystrobin is applied early in the sugar beet growing season in north-central United States for control of Rhizoctonia damping-off and Rhizoctonia crown and root rot caused by Rhizoctonia solani anastomoses groups (AGs) 4 and 2-2, respectively. Fungicide application timings based on crop growth stage and soil temperature thresholds were evaluated in inoculated small-scale trials and in commercial fields with a history of Rhizoctonia crown and root rot. Soil temperature thresholds of 10,15 , and $20^{\circ} \mathrm{C}$ were selected for fungicide application timings and used to test whether soil temperature could be used to better time applications of azoxystrobin. In both small- and large-plot trials, timing applications after attainment of specific soil temperature thresholds did not improve efficacy of azoxystrobin in controlling damping-off or Rhizoctonia crown and root rot compared with application timings based on either planting date, seedling development, or leaf stage in a susceptible (E-17) and a resistant (RH-5) cultivar. Application rate and split application timings of azoxystrobin had no significant effect on severity of crown and root rot. Other environmental factors such as soil moisture may interact with soil temperature to influence disease development. $\mathrm{Cv}$. $\mathrm{RH}-5$ had higher sugar yield attributes than the susceptible cultivar (E-17) in seasons conducive and nonconducive to crown and root rot development. All isolates recovered from both small- and large-plot trials in all years were AG 2-2. $R$. solani AG 4 was not identified in any samples from any year.
\end{abstract}

Additional keywords: Beta vulgaris

Rhizoctonia solani Kühn anastomosis group (AG) 2-2, cause of Rhizoctonia crown and root rot, is the most common and serious soilborne pathogen of sugar beet (Beta vulgaris L.) in Michigan. Economic losses and damage can vary greatly (from 0 to $50 \%$ ) from field to field depending on the level of cultivar resistance, amount of over-wintered inoculum, and environmental conditions $(1,10,19)$. Plants affected by $R$. solani wilt or die early in the season and foliar symptoms that appear later include blackening of petioles and yellowing and sudden wilting of leaves. Although disease may develop slowly at first, with no damping-off apparent, the infection continues to progress, resulting in crown and root rot later in the season (6). Root rot usually starts near the crown, spreads over the root surface, and penetrates into the root (18). Symptoms on the

Corresponding author: W. W. Kirk

E-mail: kirkw@msu.edu

Accepted for publication 5 March 2008.

doi:10.1094/PDIS-92-7-1091

(C) 2008 The American Phytopathological Society lower part of the root are sometimes observed in the absence of crown rot in Michigan.

Infection is thought to occur early in the season by movement of infested soil into the crown during cultivation $(1,10)$. In Michigan, sugar beet is planted when soil temperature reaches about 5 to $10^{\circ} \mathrm{C}$. Growth of $R$. solani AG 2-2 is optimal between 25 to $28^{\circ} \mathrm{C}$ when soils are wet $(1,16)$, and a rapid increase in soil temperature to about $20^{\circ} \mathrm{C}$ has been positively correlated with severity of crown and root rot (1). However, soil temperature from planting in April through leaf stage six to eight in mid-May to early June ranges from about 10 to $20^{\circ} \mathrm{C}$ in Michigan. These temperatures result in limited leaf development and growth $(13,14)$. Thus, temperatures during this period are not optimal for growth of the host or pathogen. Our hypothesis is that, as long as soil and root temperature are above the base temperatures for mycelial growth and plant development, infection can occur.

$R$. solani AG 2-2 can also cause postemergence damping-off. Although AG 4 is thought to be more commonly involved in damping-off in other locations (18), it has not been isolated from symptomatic plants in Michigan since at least 2001 (J. M. McGrath, personal communication). $R$. solani AG 4 also can cause superficial lesions of older beet roots (18).

Azoxystrobin applied at planting can delay early infection and enhance establishment of vigorous stands $(8-10,19)$ but does not completely prevent infections and development of crown and root rot later in the season (10). Economic constraints have led to practices that attempt to control both phases of this disease with a single fungicide application made in the early portion of the season, either at planting or when plants are immature (up to growth stage [GS] 6 to $8[9,18])$. However, season-long control of Rhizoctonia crown and root rot has not been achieved by the use of fungicides alone (10). Using fungicides in combination with genetic resistance integrates two key principals of crop protection and could enhance disease control. Resistance to Rhizoctonia crown and root rot has been reported but may be correlated with reduced yield potential of up to $15 \%$ compared with some susceptible, approved cultivars (7). There is a need for a crop protection approach that will allow growers to plant high-yielding cultivars even in fields with histories of severe disease.

Protection of sugar beet against $R$. solani is critical to obtain uniform, vigorous stands and achieve maximum root and sugar yields (10). We sought to determine whether there was an optimal application timing of azoxystrobin for control of $R$. solani on sugar beet and compared two approaches, the first based on crop development and the second based on soil temperature. The objectives of these studies were to evaluate the efficacy of fungicides applied at different crop stages or at various soil temperature thresholds for control of Rhizoctonia damping-off and Rhizoctonia crown and root rot on a susceptible and resistant sugar beet cultivar.

\section{MATERIALS AND METHODS}

Fungal isolates. Several isolates of $R$. solani were obtained from sugar beet plants with crown and root rot symptoms (AG 2-2, all from Michigan) or dampingoff (AG 4, from Colorado from the culture collection of McGrath and Hanson, Michigan State University [MSU]). Isolate AG was confirmed with molecular diagnostics (17). Axenic cultures were obtained by 
culturing the isolates on Rhizoctoniaselective medium (12). The cultures then were transferred to potato dextrose agar (PDA) and maintained at $8^{\circ} \mathrm{C}$ in the dark in an incubator (Model 136LLVL; Percival Scientific, Perry, IA).

Soil temperature thresholds and field soil temperature recording. Selection of soil temperature thresholds (STTs) for fungicide application was guided by fungal growth in vitro in relation to a range of soil temperatures (unpublished data). The range of selected temperatures also was based on mean daily soil temperatures recorded at a depth of $6 \mathrm{~cm}$ in a sugar beet field in Saginaw County, MI by the Michigan Automated Weather Network (MAWN) from April to June in 2000 and 2003 (Table 1). Finally, soil temperatures were selected so that differences between succeeding thresholds would enable fungicide applications to be made with a temporal separation of at least 5 days. The soil temperatures 10,15 , and $20^{\circ} \mathrm{C}$, satisfied the criteria above and were selected as STTs to signal application of fungicides to the plots.

Field climatic variables at the Linwood Farm (Bay County, MI) were measured with a CR10X datalogger (Campbell Scientific Instruments, Logan, UT) equipped with soil temperature sensors located at a depth of $6 \mathrm{~cm}$. Soil temperature data from planting to harvest were downloaded daily to a PC via a cellular modem connection to the datalogger. The soil temperature was monitored and fungicide applications were made on or within 1 day of reaching the threshold.

Small-plot trials. Field trials were established over 3 years at the MSU Bean and Beet Research Farm, St. Charles, Saginaw County, MI. The previously planted crop was dry bean (Phaseolus vulgaris) in each year from 2003 to 2005. Sugar beet cv. E-17 (susceptible to $R$. solani AG 2-2) was PAT-treated (Priming Advance Treatment; Seed Systems Inc., Gilroy, CA) and planted on 18 April 2003, 11 April 2004, and 22 April 2005. Seed was planted at a $2.5-\mathrm{cm}$ depth into fourrow plots (approximately $10 \mathrm{~cm}$ between plants) $15.4 \mathrm{~m}$ long with $0.76 \mathrm{~m}$ between rows. Treatments (described below) were replicated four times in a randomized complete block design. Fertilizer was drilled into plots immediately before planting, and was formulated according to results of soil tests (46-0-0 at $60 \mathrm{~kg} / \mathrm{ha})$. No additional nitrogen was applied to the growing crop.

Inoculum was produced in bulk by growing $R$. solani on millet seed $(1,500$ $\mathrm{cm}^{3}$ ) which was placed in Sterilizable Airflow Spawn Bags (53 by 209 by $110 \mathrm{~cm}$; Fungi Perfecti LLC., Shelton, WA) to which $500 \mathrm{ml}$ of sterile distilled water was added. The bags were sealed with an impulse sealer (model number AIE-300; American International Electric Inc., Whittier, CA), then autoclaved twice at $115^{\circ} \mathrm{C}$ for $30 \mathrm{~min}$. When the medium cooled to $\leq 40^{\circ} \mathrm{C}, 105$-mm-diameter plugs from the axenic cultures of $R$. solani AG 2-2 and AG 4 were added to separate millet bags. The bags were resealed with the impulse sealer, mixed by hand-shaking, and incubated for up to 28 days at $18^{\circ} \mathrm{C}$ in the dark until used.

Millet seed infested with $R$. solani (AG 2-2 and AG 4) was broadcast over the center two rows of each plot of emerged sugar beet plants at GS 2 to 4 at a rate of $750 \mathrm{~g}$ of $R$. solani-infested millet seed inoculum (each AG) per $30.8 \mathrm{~m}$ of row length. Trials were inoculated on 15 May 2003, 1 May 2004, and 12 May 2005.

In 2003 and 2004, fungicide applications were timed based on GS of the sugar beet plants. In 2003, planting, emergence, GS 2 to 4 and GS 4 to 6 , occurred on 18 and 28 April and 8 and 18 May, respectively; and in 2004, planting, preemergence, emergence, GS 2 to 4, GS 4 to 6 , and GS 6 to 8, occurred on 11, 13, 21 April and 1, 11, and 21 May, respectively. In 2005, fungicides were applied at planting, pre-emergence, emergence, GS 2 to 4 , GS 4 to 6 , and GS 6 to $8-$ which occurred on 22 and 24 April, 2, 12, and 25 May, and 1 June, respectively. In 2004 and 2005, fungicides also were applied at attainment of a STT of 10,15 , and $20^{\circ} \mathrm{C}$ on 10,13 , and 31 May 2004 and on 10 and 25 May and 3 June 2005, respectively. The dates of attainment of the different GS were similar in each year in terms of days after planting.

In-furrow treatments of azoxystrobin were applied with a tractor-mounted spray boom (R\&D Inc., LA) delivering 94 liters/ha at $276 \mathrm{kPa} /$ row with one XR11003VS nozzle (Lechler Inc., IL) at 0.008 and $0.011 \mathrm{~kg}$ a.i. per $1,000-\mathrm{m}$ row in 2003 and $0.008 \mathrm{~kg}$ a.i. per $1,000-\mathrm{m}$ row in 2004 and 2005, respectively. Post-planting, pre-emergence (PE), and at-emergence (E) applications of azoxystrobin were made in

Table 1. Date after which soil temperature at $6 \mathrm{~cm}$ depth reached and remained at or above the indicated threshold for seven consecutive days in Saginaw County, MI from 2001 to 2006

\begin{tabular}{lcccccc}
\hline & \multicolumn{5}{c}{ Date of attainment of soil temperature thresholds } \\
\cline { 2 - 7 } STT $\left({ }^{\circ} \mathbf{C}\right)^{\mathbf{z}}$ & $\mathbf{2 0 0 1}$ & $\mathbf{2 0 0 2}$ & $\mathbf{2 0 0 3}$ & $\mathbf{2 0 0 4}$ & $\mathbf{2 0 0 5}$ & $\mathbf{2 0 0 6}$ \\
\hline 10 & 1 May & 6 May & 15 May & 9 May & 7 May & 12 April \\
15 & 18 May & 30 May & 7 June & 12 May & 22 May & 1 May \\
20 & 27 June & 22 June & 22 June & 30 May & 2 June & 6 June \\
\hline
\end{tabular}

${ }^{\mathrm{z}}$ STT $=$ soil temperature threshold.
2004 and 2005 using a single nozzle delivering 94 liters/ha. PE and E applications were made at 0.008 and $0.011 \mathrm{~kg}$ a.i. per $1,000-\mathrm{m}$ row in $2003 ; 0.011 \mathrm{~kg}$ a.i. per $1,000-\mathrm{m}$ row in 2004; and 0.011 and 0.093 $\mathrm{kg}$ a.i. per $1,000-\mathrm{m}$ row in 2005 . Applications up to GS 2 to 4 (B) were made with a single nozzle at 94 liters $/$ ha at $0.011 \mathrm{~kg}$ a.i. per 1,000-m row in 2003 and 2004 but at $0.093 \mathrm{~kg}$ a.i. per $1,000-\mathrm{m}$ row in 2005 . The rate for foliar-banded application was $0.224 \mathrm{~kg}$ a.i./ha in 233 liters of $\mathrm{H}_{2} \mathrm{O} / \mathrm{ha}$ at $552 \mathrm{kPa}$ with nozzles spaced at $30 \mathrm{~cm}$ in all years and included timings based on STTs (see above). Azoxystrobin was formulated as Quadris 2.08SC (Syngenta Crop Protection Inc., Greensboro, NC) in the 2003 trial and as Amistar 80WDG (Syngenta Crop Protection Inc.) in 2004 and 2005 trials.

Weeds were controlled by cultivation and with a mixture of pyrazon DF (Pyramin, Micro Flo Company LLC, Memphis, TN) at $5.6 \mathrm{~kg} / \mathrm{ha}$ plus ethofumesate (Nortron; Bayer CropScience, Research Triangle Park, NC) at 38 liters/ha applied at planting. Cercospora leaf spot (Cercospora beticola) was managed by single applications of tetraconazole (Eminent 125SL; Sipcam Agro USA, Inc., Roswell, GA) on 15 July 2003, 4 August 2004, and 10 August 2005. Application in each year was initiated after 55 Beetcast disease severity values were recorded in the area (Ontario Weather Network, University of Guelph, Ridgetown Campus, Ontario, Canada).

Large-plot trials. Field trials were established over 3 years in different fields at Linwood, Bay County, MI that had a history of crown and root rot. The previously planted crop was dry bean in each year from 2003 to 2005. Sugar beet cvs. E-17 (susceptible to $R$. solani) and RH5 (resistant to $R$. solani) were PAT-treated and planted on 26 April 2003, 5 April 2004, and 14 April 2005. In each year, germination tests indicated that not less than $95 \%$ of seed germinated. Cv. RH5 was included as a resistant check cultivar and a limited number of treatments (in-furrow or an application at GS 2 to 4) were tested. Seed was planted at a depth of $2.54 \mathrm{~cm}$ into sixrow plots (approximately $10 \mathrm{~cm}$ between plants) $60 \mathrm{~m}$ long with $0.76 \mathrm{~m}$ between rows. Treatments were replicated four times in a randomized complete block design. Fertilizer and fungicides were applied as described above and weeds were controlled as described above. Cercospora leaf spot was managed by applications of tetraconazole (Eminent 125SL) followed by pyraclostrobin (Headline Fungicide; BASF Ag Products, Research Triangle Park, NC) on 20 July and 13 August 2003 and on 11 July and 16 August 2005 and tetraconazole followed by triphenyltin $\mathrm{OH}$ (Super Tin 80WP; E.I. du Pont de Nemours and Company, Wilmington, DE) on 4 August and 2 September 2004. The ini- 
tial application in each year was initiated after 55 Beetcast disease severity values were recorded in the area (Ontario Weather Network). No inoculum was applied to the large-plot field trials.

In 2003, fungicides were applied at planting (in-furrow), GS 2 to 4 and GS 6 to 8 , and in combinations of applications (infurrow followed by GS 6 to 8 and GS 2 to 4 followed by GS 6 to 8 treatments). Infurrow applications were made on 26 April, and GS 2 to 4 and GS 6 to 8 applications on 16 and 26 May, respectively. In 2004, fungicides were applied at planting, pre-emergence, emergence, and GS 2 to 4, GS 4 to 6 , and GS 6 to 8 on $5,8,15$, and 25 April and 5 and 15 May, respectively, and attainment of STT of $10^{\circ} \mathrm{C}$ on 18 April, $15^{\circ} \mathrm{C}$ on 10 May, and $20^{\circ} \mathrm{C}$ on 20 May. In 2005, fungicides were applied at planting, pre-emergence, emergence, and GS 2 to 4, GS 4 to 6 , and GS 6 to 8 on 14, 17, and 25 April and 5, 15, and 26 May, respectively, and attainment of STT of $10^{\circ} \mathrm{C}$ on 30 April, $15^{\circ} \mathrm{C}$ on 9 May, and $20^{\circ} \mathrm{C}$ on 8 June. In 2005 , soil temperature was variable for 6 days following planting; although average soil temperatures of $10^{\circ} \mathrm{C}$ were attained, applications of fungicides were withheld until after emergence.

Data collection. In small- and large-plot trials, plant stand was measured as the number of plants emerged about 10, 20, and 30 days after planting (DAP) and 5 days prior to harvest but only for treatments that were applied up to 20 days after emergence. Treatments applied after this cut-off point would have no effect on emergence or plant stand. Data were expressed as percent emerged plants over four rows by $15.4 \mathrm{~m}$ (small-plot trials) or $90 \mathrm{~m}$ (large-plot trials), based on a potential population of 1,000 plants per $1,000 \mathrm{~m}$ of row. In the large-plot field trials, plant stand data were collected from the preemergence treatments only. Rhizoctonia crown and root rot incidence was measured as the percentage of plants with symptoms of crown and root rot (19) and was confirmed by laboratory diagnosis (1) 5 days prior to harvest. Beet roots were machine harvested on 27 August 2003, 14 August 2004, and 7 September 2005 in the small-plot trials and 7 November 2003, 26 October 2004, and 5 November 2005 in the large-plot trials. Individual treatments were weighed in all field trials. Sucrose concentration and clear juice purity (CJP) were determined from samples of 10 beet roots per plot sampled from the large-plot trials only. Recoverable white sucrose per metric ton (t) of sugar beet (RWST kg) and recoverable white sucrose per hectare $(\mathrm{RWSHa}=\mathrm{t} / \mathrm{ha} \times \mathrm{RWST})$ were determined at the Michigan Sugar Company laboratory in Saginaw, MI. All data were analyzed by the "Fit Model" standard least squares platform using two models: (i) three-way full factorial with mixed effects and (ii) two-way analysis of variance with interaction using the statistical software package JMP 5.0.1.2 (SAS Institute, Cary, NC)

DNA isolation, polymerase chain reaction, and DNA sequencing for diagnostics. In each year, isolates (five per plot) of $R$. solani were collected from all sites (see field experiments above). Isolates were collected from five sugar beet plants, arbitrarily selected, showing symptoms of damping-off early in the season (during May) and crown and root rot later in the season (September). Cultures were isolated on selective medium as described above. Polymerase chain reaction (PCR) was done by modifying the protocol from Salazar et al. (17). Mycelia were scraped from the cultures using a rubber policeman and DNA was extracted from the mycelia using a Qiagan DNeasy Plant mini kit (cat. no. 69104; Qiagan Sciences, MD). PCR products were analyzed by electrophoresis on $1 \%$ gels in Tris-acetate-EDTA buffer at 110 $\mathrm{V}$ for $1 \mathrm{~h}$. Isolates with PCR products that amplified at approximately $700 \mathrm{bp}$ were cleaned using QIAquick PCR Purification kit (cat. no. 28104; Qiagan Sciences) and submitted for sequencing to the Genomics Technology Support Facility at MSU. The Blastn algorithm was used to compare nucleotide sequences and this sequence information was used for identification of species.

\section{RESULTS}

DNA isolation, PCR, and DNA sequencing for diagnostics. All isolates recovered from symptomatic plants from both the small-plot and large-scale trials at both sampling timings (damping-off during May and crown and root rot during September) in each year of the experiments were $R$. solani AG 2-2 IIIB and AG 2-2 IV in equal proportions. $R$. solani AG 4 was not identified from any of the samples in any year.

Small-plot trials. In 2003, applications based on soil temperature were not used. Plant stand establishment was not affected by in-furrow or early fungicide applications of azoxystrobin from 14 to 40 DAP from 2003 to 2005 (Table 2). Stand establishment was greatest in the 2003 trial. Plant stand decreased over the season, particularly in nontreated plots, in 2003 and 2004 but not in 2005. In 2003, the infurrow application of azoxystrobin (0.011 $\mathrm{kg}$ a.i. per 1,000-m row length), the application at emergence of $0.008 \mathrm{~kg}$ a.i. per $1,000-\mathrm{m}$ row length, and the banded and foliar broadcast applications of azoxystrobin resulted in significantly greater plant stand by 126 DAP than the nontreated control. Only the application of azoxystrobin 80 WDG $(0.011 \mathrm{~kg}$ a.i. per $1,000-\mathrm{m}$ row length) made at emergence resulted in significantly greater plant stand compared with the nontreated control in 2004 and there were no significant differences among fungicide treatments (Table 2).
Crown and root rot developed consistently throughout the season in each year, especially in the nontreated control plots. In the nontreated control plots, incidence of crown and root rot was $35.6 \%$ in 2003 , $57.8 \%$ in 2004, and $12.3 \%$ in 2005 (Table 2). In 2003, the in-furrow application of azoxystrobin at $0.011 \mathrm{~kg}$ a.i. per $1,000-\mathrm{m}$ row length, the at-emergence application of $0.008 \mathrm{~kg}$ a.i. per $1,000-\mathrm{m}$ row length, and both the banded and foliar broadcast applications of azoxystrobin resulted in significantly lower incidence of crown and root rot than the nontreated control but there were no significant differences among treatments. In 2004 and 2005, all treatments, including those triggered by soil temperature, had significantly lower incidence of crown and root rot than the nontreated control but there were no significant differences among treatments (Table 2).

The yield of nontreated control plots was $34.4,40.5$, and $38.1 \mathrm{t} / \mathrm{ha}$ in 2003 , 2004 , and 2005, respectively (Table 2). In 2003, in-furrow applications of azoxystrobin at both rates and the foliar application of azoxystrobin $(0.224 \mathrm{~kg}$ a.i./ha) had significantly greater yield than the nontreated control. Azoxystrobin applied at leaf stage 2 to 4 had significantly greater yield $(66.0 \mathrm{t} / \mathrm{ha})$ than applications at emergence or the broadcast application. In 2004 and 2005, there were no significant differences in yield among treatments (Table 2).

Large-plot trials. There were significant interactions among year, cultivar, and treatment in all variables except yield and CJP (Table 3). The degrees of freedom (df) for the plant stands were different from those for the other evaluations because plant stand was determined only from plants exposed to a treatment prior to 30 DAP. Therefore, the data were analyzed and presented by year.

In 2003, applications based on soil temperature were not used. Plant establishment at 10 DAP was significantly reduced by in-furrow fungicide applications of azoxystrobin in cv. RH-5 10 DAP but no differences were found at 20 or 30 DAP. The in-furrow application of azoxystrobin to RH-5 significantly increased plant stand compared with the nontreated control at harvest (Table 4).

There were no differences in plant stand from 10 to 30 DAP in cv. E-17 among treatments but, in $\mathrm{RH}-5$, the nontreated plots had significantly higher plant stand than the in-furrow application of azoxystrobin 10 DAP (Table 4). At harvest, all treatments had significantly higher plant stand than the nontreated control in E-17, and the in-furrow followed by a foliar application of azoxystrobin treatment had the greatest plant stand. In RH-5, the infurrow application of azoxystrobin treatment had greater plant stand at harvest than the nontreated control (Table 4).

Crown and root rot developed consistently through the season and incidence in 
the E-17 and RH-5 nontreated control plots was 39.7 and $17.4 \%$, respectively (Table 4). All treatment timings of azoxystrobin reduced the incidence of crown and root rot compared with the nontreated controls for both cultivars. In E-17, the split application of azoxystrobin infurrow followed by application at GS 6 to 8 had significantly lower incidence of crown and root rot than single applications at GS 2 to 4 and GS 6 to 8 . There were no differences among other treat- ments. There were no significant differences among other treatments in E-17. In $\mathrm{RH}-5$, the in-furrow application of azoxystrobin treatment had significantly better control of crown and root rot than the nontreated control (Table 4).

Table 2. Effect of timing of azoxystrobin application on plant stand, incidence of crown and root rot, and yield in sugar beet cv. E-17 inoculated after emergence with Rhizoctonia solani AG 2-2 and AG 4, 2003 to 2005

\begin{tabular}{|c|c|c|c|c|c|c|c|c|c|}
\hline \multirow[b]{2}{*}{ Year, rate ${ }^{v}$} & \multicolumn{3}{|c|}{ Application } & \multicolumn{4}{|c|}{ Plant stand $(\%)^{\mathrm{u}}$} & \multirow[b]{2}{*}{$\operatorname{Rot}(\%)^{x}$} & \multirow[b]{2}{*}{ Yield (t/ha) } \\
\hline & Date & DAP & Treatment $^{\mathrm{w}}$ & First & Second & Third & Fourth & & \\
\hline \multicolumn{10}{|l|}{2003} \\
\hline $0.008(\mathrm{~km})$ & April 18 & 0 & IF & 68.6 & 88.9 & 90.4 & $80.2 b c^{y}$ & $24.8 \mathrm{~b}$ & $55.4 \mathrm{abc}$ \\
\hline $0.011(\mathrm{~km})$ & April 18 & 0 & IF & 77.4 & 90.5 & 90.9 & $86.6 \mathrm{ab}$ & $17.4 \mathrm{bc}$ & $55.7 \mathrm{abc}$ \\
\hline $0.008(\mathrm{~km})$ & April 28 & 10 & $\mathrm{E}$ & 80.0 & 89.3 & 91.6 & $82.5 \mathrm{~b}$ & $22.5 \mathrm{~b}$ & $40.6 \mathrm{~cd}$ \\
\hline $0.011(\mathrm{~km})$ & April 28 & 10 & $\mathrm{E}$ & 77.4 & 88.0 & 92.6 & $82.4 \mathrm{bc}$ & $22.6 \mathrm{~b}$ & $47.4 \mathrm{bcd}$ \\
\hline $0.011(\mathrm{~km})$ & May 8 & 20 & $\mathrm{~B}$ & 69.8 & 89.5 & 89.6 & $86.5 \mathrm{ab}$ & $18.5 \mathrm{bc}$ & $44.6 \mathrm{bcd}$ \\
\hline 0.224 (ha) & May 18 & 30 & $\mathrm{FB}_{\mathrm{a}}$ & $\ldots$ & $\ldots$ & $\ldots$ & $87.5 \mathrm{a}$ & $17.5 \mathrm{bc}$ & $66.0 \mathrm{a}$ \\
\hline Nontreated & $\ldots$ & $\ldots$ & $\ldots$ & 79.0 & 83.2 & 86.3 & $69.4 \mathrm{c}$ & $35.6 \mathrm{a}$ & $34.4 \mathrm{~d}$ \\
\hline $\mathrm{HSD}^{\mathrm{z}}$ & $\ldots$ & $\ldots$ & $\ldots$ & 12.18 & 13.71 & 12.34 & 13.04 & 9.26 & 17.21 \\
\hline \multicolumn{10}{|l|}{2004} \\
\hline $0.008(\mathrm{~km})$ & April 11 & 0 & IF & 20.1 & 57.4 & 55.9 & $52.2 \mathrm{ab}$ & $7.3 \mathrm{~b}$ & 51.0 \\
\hline $0.011(\mathrm{~km})$ & April 13 & 2 & PE & 21.3 & 59.0 & 57.5 & $47.0 \mathrm{ab}$ & $23.0 \mathrm{~b}$ & 41.4 \\
\hline $0.011(\mathrm{~km})$ & April 21 & 10 & $\mathrm{E}$ & 25.9 & 58.8 & 59.2 & $53.6 \mathrm{a}$ & $10.5 \mathrm{~b}$ & 44.0 \\
\hline $0.011(\mathrm{~km})$ & May 1 & 20 & B & $\ldots$ & $\ldots$ & $\ldots$ & $46.8 \mathrm{ab}$ & $24.6 \mathrm{~b}$ & 50.8 \\
\hline 0.224 (ha) & May 11 & 30 & $\mathrm{FB}_{\mathrm{a}}$ & $\ldots$ & $\ldots$ & $\ldots$ & $51.7 \mathrm{ab}$ & $13.5 \mathrm{~b}$ & 56.9 \\
\hline 0.224 (ha) & May 21 & 40 & $\mathrm{FB}_{\mathrm{b}}$ & $\ldots$ & $\ldots$ & $\ldots$ & $52.0 \mathrm{ab}$ & $15.1 \mathrm{~b}$ & 46.3 \\
\hline 0.224 (ha) & May 10 & 29 & $\mathrm{STT}_{1}$ & $\ldots$ & $\ldots$ & $\ldots$ & $52.6 \mathrm{ab}$ & $15.6 \mathrm{~b}$ & 47.6 \\
\hline 0.224 (ha) & May 13 & 32 & $\mathrm{STT}_{2}$ & $\ldots$ & $\ldots$ & $\ldots$ & $51.8 \mathrm{ab}$ & $14.7 \mathrm{~b}$ & 48.7 \\
\hline 0.224 (ha) & May 31 & 50 & $\mathrm{STT}_{3}$ & $\ldots$ & $\ldots$ & $\ldots$ & $50.7 \mathrm{ab}$ & $16.2 \mathrm{~b}$ & 44.6 \\
\hline Nontreated & $\ldots$ & $\ldots$ & $\ldots$ & 24.1 & 54.6 & 55.6 & $35.6 \mathrm{~b}$ & $57.8 \mathrm{a}$ & 40.5 \\
\hline HSD & $\ldots$ & $\ldots$ & $\ldots$ & 9.33 & 11.84 & 12.50 & 16.94 & 26.80 & 17.50 \\
\hline \multicolumn{10}{|l|}{2005} \\
\hline $0.008(\mathrm{~km})$ & April 22 & 0 & $\mathrm{IF}$ & 2.1 & 51.9 & 54.0 & 48.0 & $4.1 \mathrm{~b}$ & 45.9 \\
\hline $0.011(\mathrm{~km})$ & April 24 & 2 & PE & 3.6 & 52.9 & 67.2 & 59.2 & $2.0 \mathrm{~b}$ & 45.9 \\
\hline $0.093(\mathrm{~km})$ & May 2 & 10 & $\mathrm{E}$ & 2.3 & 52.2 & 61.8 & 58.3 & $3.5 \mathrm{~b}$ & 46.6 \\
\hline 0.093 (ha) & May 12 & 20 & $\mathrm{~B}$ & $\ldots$ & $\ldots$ & $\ldots$ & 55.1 & $2.5 \mathrm{~b}$ & 48.8 \\
\hline 0.224 (ha) & May 25 & 33 & $\mathrm{FB}_{\mathrm{a}}$ & $\ldots$ & $\ldots$ & $\ldots$ & 56.3 & $5.5 \mathrm{~b}$ & 46.1 \\
\hline 0.224 (ha) & June 1 & 40 & $\mathrm{FB}_{\mathrm{b}}$ & $\ldots$ & $\ldots$ & $\ldots$ & 50.0 & $3.6 \mathrm{~b}$ & 40.5 \\
\hline 0.224 (ha) & May 10 & 18 & $\mathrm{STT}_{1}$ & $\ldots$ & $\ldots$ & $\ldots$ & 59.9 & $3.9 \mathrm{~b}$ & 42.1 \\
\hline 0.224 (ha) & May 25 & 33 & $\mathrm{STT}_{2}$ & $\ldots$ & $\ldots$ & $\ldots$ & 59.4 & $4.8 \mathrm{~b}$ & 45.7 \\
\hline 0.224 (ha) & June 3 & 42 & $\mathrm{STT}_{3}$ & $\ldots$ & $\ldots$ & $\ldots$ & 59.2 & $2.7 \mathrm{~b}$ & 42.1 \\
\hline Nontreated & $\ldots$ & $\ldots$ & $\ldots$ & 4.3 & 54.5 & 62.2 & 57.4 & $12.3 \mathrm{a}$ & 38.1 \\
\hline HSD & $\ldots$ & $\ldots$ & $\ldots$ & 7.10 & 17.8 & 19.8 & 12.25 & 8.67 & 15.72 \\
\hline
\end{tabular}

" First, second, third, and fourth applications were 14, 28, 40, and 126 days after planting (DAP), respectively, in 2003; 10, 20, 30, and 120 DAP in 2004; and $10,20,30$, and 137 DAP in 2005.

$\checkmark$ Trials were inoculated on 15 May 2003, 1 May 2004, and 12 May 2005. Rate shown in kg a.i. per 1,000-m row (km) or per hectare (ha).

${ }^{\mathrm{w}} \mathrm{IF}=$ in-furrow at planting; $\mathrm{PE}=$ pre-emergence; $\mathrm{E}=$ at emergence; $\mathrm{B}=10$-cm banded application applied only at growth stage (GS) 2 to 4 ; FB = foliar broadcast application, $\mathrm{FB}_{\mathrm{a}}=$ applied only at GS 4 to $6, \mathrm{FB}_{\mathrm{b}}=$ applied only at GS 6 to 8; STT = soil temperature threshold-generated application timings, where $\mathrm{STT}_{1}, \mathrm{STT}_{2}$, and $\mathrm{STT}_{3}$ are equivalent to reaching mean daily soil temperatures of 10,15 , and $20^{\circ} \mathrm{C}$ at a 6.0 -cm depth, respectively, all broadcast.

${ }^{x}$ Crown and root rot incidence.

y Values within a column followed by the same letter are not significantly different (Tukey's multiple comparison at $P=0.05$ ).

${ }^{\mathrm{z}} \mathrm{HSD}=$ honestly significant difference, $P=0.05$.

Table 3. Main and interaction effects of analyses of variance measured as $P$ values of timing of azoxystrobin application on plant stand, incidence of crown and root rot, yield, and sucrose content in sugar beet exposed to natural inoculum of Rhizoctonia solani AG 2-2 at Linwood, MI, 2003 to 2005

\begin{tabular}{|c|c|c|c|c|c|c|c|c|c|c|c|c|}
\hline \multirow[b]{3}{*}{ Variables } & \multirow{2}{*}{\multicolumn{2}{|c|}{ df $\mathbf{u}$}} & \multicolumn{10}{|c|}{$P$ values } \\
\hline & & & \multicolumn{4}{|c|}{ Plant stand $(\%)^{\mathrm{v}}$} & \multirow[b]{2}{*}{$\operatorname{Rot}(\%)^{x}$} & \multirow[b]{2}{*}{ Yield (t/ha) } & \multirow[b]{2}{*}{ Sucrose (\%) } & \multirow[b]{2}{*}{ CJP $(\%)^{\mathbf{y}}$} & \multirow[b]{2}{*}{ RWST $^{z}$} & \multirow[b]{2}{*}{$\mathbf{R W S H a}^{\mathrm{z}}$} \\
\hline & Stand & Other $^{w}$ & 10 DAP & 20 DAP & 30 DAP & Harvest & & & & & & \\
\hline Year & 2 & 2 & $<0.0001$ & $<0.0001$ & $<0.0001$ & $<0.0001$ & $<0.0001$ & $<0.0001$ & $<0.0001$ & $<0.0001$ & $<0.0001$ & $<0.0001$ \\
\hline Cultivar (Cv.) & 1 & 1 & $<0.0001$ & 0.0068 & 0.017 & $<0.0001$ & $<0.0001$ & $<0.0001$ & 0.8067 & 0.2394 & 0.5469 & $<0.0001$ \\
\hline Treatment (Trt.) & 2 & 9 & $<0.0001$ & $<0.0001$ & 0.099 & 0.0004 & $<0.0001$ & $<0.0001$ & 0.0029 & 0.9979 & 0.0084 & $<0.0001$ \\
\hline Year $\times \mathrm{Cv}$ & 2 & 2 & 0.0025 & 0.0002 & $<0.0001$ & 0.0001 & $<0.0001$ & 0.0006 & $<0.0001$ & 0.2120 & $<0.0001$ & $<0.0001$ \\
\hline Year $\times$ Trt & 4 & 6 & 0.0342 & 0.0033 & $<0.0001$ & $<0.0001$ & $<0.0001$ & $<0.0001$ & $<0.0001$ & 0.8465 & $<0.0001$ & $<0.0001$ \\
\hline Cv. $\times$ Trt. & 2 & 4 & $<0.0001$ & 0.0629 & 0.222 & $<0.0001$ & $<0.0001$ & 0.0206 & $<0.0001$ & 0.6562 & 0.0051 & $<0.0001$ \\
\hline Year $\times$ Cv. $\times$ Trt. & 4 & 6 & $<0.0001$ & 0.0296 & 0.0365 & $<0.0001$ & $<0.0001$ & 0.6803 & 0.0003 & 0.7933 & 0.016 & 0.0513 \\
\hline
\end{tabular}

u df = degrees of freedom.

v Plant stand data for days 10 to 30 were taken for pre-emergence treatments only. DAP $=$ days after planting.

${ }^{w}$ All other evaluations.

${ }^{x}$ Crown and root rot incidence.

y Clear juice purity.

${ }^{\mathrm{z}}$ RWST $=$ recoverable white sucrose per ton and $\mathrm{RWSHa}=$ recoverable white sucrose per hectare. 
All treatments of azoxystrobin increased the yield in E-17 and RH-5 compared with the respective nontreated controls (Table 4). In E-17, the highest yielding treatments were both in-furrow applications and the split low-rate foliar-banded application treatment. Sucrose content (percent) in E17 was greater in all treatments of azoxystrobin compared with the nontreated control. In RH-5, sucrose content (percent) was greater in the azoxystrobin-treated plots compared with the nontreated control. CJP was not affected by any treatments in either cultivar. RWST/kg was significantly increased compared with the nontreated control in E-17 and RH-5. In E17, all treatments increased the RWSHa compared with the nontreated control $(1,488 \mathrm{~kg})$, and the in-furrow and in furrow and foliar split treatment had significantly greater RWSHa values than any other treatments. In RH-5, the in-furrow application of azoxystrobin resulted in a significantly higher RWSHa $(5,652 \mathrm{~kg})$ than the nontreated control (Table 4).

In addition to the at-planting and infurrow treatments, applications based on STT were included in 2004 and 2005. The in-furrow and pre-emergence applications of azoxystrobin to E-17 significantly decreased plant stand compared with the nontreated control measured 20 DAP but had no effect by 30 DAP (Table 5). In cv. RH-5 in 2004, plant establishment was not affected by the in-furrow application of azoxystrobin at 10 or 20 DAP; however, the in-furrow application of azoxystrobin significantly increased plant stand by 30 DAP (Table 5). Plant stand was reduced over the season and was $40 \%$ in the nontreated cv. E-17 by 149 DAP (Table 5).
In E-17, applications of azoxystrobin made in-furrow, at GS 2 to 4,4 to 6 , or 6 to 8 , or at $\mathrm{STT}_{2}\left(15^{\circ} \mathrm{C}\right)$ resulted in higher plant stand at harvest than in the nontreated control (Table 5). In RH-5, no application timings resulted in significantly different percent plant stand from that of the nontreated control but the in-furrow application resulted in significantly higher percent plant stand than that of the application at GS 2 to 4.

In 2004, crown and root rot developed consistently through the season and incidence in the E-17 and RH-5 nontreated control plots was 44.9 and $7.1 \%$, respectively (Table 5). Incidence of crown and root rot was not affected by the in-furrow or foliar application of azoxystrobin in $\mathrm{cv}$. RH-5. All treatment timings of azoxystrobin significantly reduced the incidence of crown and root rot compared with the nontreated controls in E-17 except the pre-emergence and the foliar fungicide application of azoxystrobin timed at $\mathrm{STT}_{3}$ $\left(20^{\circ} \mathrm{C}\right)$. The in-furrow application of azoxystrobin to E-17 significantly reduced the incidence of crown and root rot compared with several other treatments but not applications timed at GS 2 to 4,4 to 6 , or 6 to 8 (Table 5).

The in-furrow application of azoxystrobin significantly increased the yield of E-17 but not of RH-5 compared with the nontreated controls (Table 5). In E-17, the highest yielding treatments were the infurrow applications and applications timed at GS 2 to 4 through 6 to 8 , although these latter applications were not significantly different from any other treatment or the nontreated control. In E-17, sucrose content was significantly greater in beet roots from treatments of azoxystrobin applied at GS 4 to 6 and 6 to 8 compared with the nontreated control. No other treatments were significantly different from the nontreated control. In RH-5, the nontreated control had the highest sucrose content in beet roots and was significantly greater than that of beet harvested from the azoxystrobin plots treated in-furrow. CJP was not affected by any of the treatments in either E-17 or RH-5. RWST in E-17 was not affected by any treatments compared with the nontreated control, although applications of azoxystrobin at GS 4 to 6 and 6 to 8 had significantly higher values than that of azoxystrobin applied at emergence or at GS 2 to 4. There were no differences in RH-5 in terms of RWST. Only the infurrow application of azoxystrobin significantly increased RWSHa compared with the nontreated control in E-17 $(3,497 \mathrm{~kg})$. No application timings of azoxystrobin affected RWSHa in RH-5 (Table 4).

In 2005, in-furrow application of azoxystrobin reduced plant establishment 21, 31 , and 40 DAP in cv. E-17 and RH-5 (Table 6). Although there were significant differences in plant stand and incidence of crown and root rot, the magnitude of the differences was small due to the lack of disease development in the dry growing season of 2005. In E-17 and RH-5, no treatments increased yield compared with the nontreated control. Application of azoxystrobin did not affect sucrose content or CJP in E-17 but significantly increased sucrose content and RWST in RH-5. In E17 , no treatments affected RWSHa compared with the nontreated control; however, treatments with $\geq 5,464 \mathrm{~kg}$ were significantly higher than the at-emergence

Table 4. Effect of timing of azoxystrobin application on plant stand, incidence of crown and root rot, yield, and sucrose content in sugar beet exposed to natural inoculum of Rhizoctonia solani AG 2-2 at Linwood, MI, USA, 2003

\begin{tabular}{|c|c|c|c|c|c|c|c|c|c|c|}
\hline \multirow[b]{2}{*}{ Cv., fungicide ${ }^{u}$} & \multicolumn{4}{|c|}{ Population (\%) at DAP ${ }^{t}$} & \multirow[b]{2}{*}{ Incidence $^{\mathrm{v}}$} & \multirow[b]{2}{*}{ Yield (t/ha) } & \multirow[b]{2}{*}{ Sucrose $(\%)$} & \multirow[b]{2}{*}{$\operatorname{CJP}(\%)^{\mathrm{w}}$} & \multirow[b]{2}{*}{ RWST $(\mathbf{k g})^{\mathrm{x}}$} & \multirow[b]{2}{*}{ RWSHa $(\mathbf{k g})^{\mathrm{x}}$} \\
\hline & 10 & 20 & 30 & $173(H)$ & & & & & & \\
\hline \multicolumn{11}{|l|}{ E-17 (S) } \\
\hline In-furrow (0) & $23 a^{y}$ & $65 \mathrm{a}$ & $66 \mathrm{a}$ & $46 \mathrm{ab}$ & $14.7 \mathrm{bc}$ & $37.4 \mathrm{ab}$ & $17.5 \mathrm{a}$ & 94.8 & $117 \mathrm{a}$ & $4,368 \mathrm{a}$ \\
\hline In-furrow $(0)+$ & $\ldots$ & $\ldots$ & $\ldots$ & $\ldots$ & $\ldots$ & $\ldots$ & $\ldots$ & $\ldots$ & $\ldots$ & $\ldots$ \\
\hline GS 6 to $8(30)$ & $21 \mathrm{a}$ & $65 \mathrm{a}$ & $66 \mathrm{a}$ & $50 \mathrm{a}$ & $9.7 \mathrm{c}$ & 38.9 a & $17.2 \mathrm{ab}$ & 94.8 & $115 \mathrm{a}$ & $4,457 \mathrm{a}$ \\
\hline GS 2 to $4(20)$ & $\ldots$ & $\ldots$ & $\ldots$ & $41 \mathrm{ab}$ & $17.3 \mathrm{~b}$ & $33.6 \mathrm{bc}$ & $16.9 \mathrm{~b}$ & 94.9 & $113 \mathrm{a}$ & $3,785 \mathrm{~b}$ \\
\hline GS 6 to $8(30)$ & $\ldots$ & $\ldots$ & $\ldots$ & $39 \mathrm{~b}$ & $17.8 \mathrm{~b}$ & $30.0 \mathrm{c}$ & $17.2 \mathrm{ab}$ & 94.8 & $115 \mathrm{a}$ & $3,439 \mathrm{e}$ \\
\hline GS 2 to $4(20)+$ & $\ldots$ & $\ldots$ & $\ldots$ & $\ldots$ & $\ldots$ & $\ldots$ & $\ldots$ & & $\ldots$ & $\ldots$ \\
\hline GS 6 to $8(30)$ & $\ldots$ & $\ldots$ & $\ldots$ & $41 \mathrm{ab}$ & $15.1 \mathrm{bc}$ & $34.1 \mathrm{bc}$ & $17.1 \mathrm{ab}$ & 94.7 & $114 \mathrm{a}$ & $3,876 \mathrm{~b}$ \\
\hline Nontreated & $21 \mathrm{a}$ & $66 \mathrm{a}$ & $66 \mathrm{a}$ & $16 \mathrm{c}$ & 39.7 a & $14.3 \mathrm{~d}$ & $15.7 \mathrm{c}$ & 94.8 & $104 \mathrm{~b}$ & $1,488 \mathrm{~d}$ \\
\hline HSD $P=0.05^{z}$ & 4.7 & 2.8 & 3.3 & 9.1 & 6.44 & 4.76 & 0.57 & 2.47 & 6.8 & 282.9 \\
\hline \multicolumn{11}{|l|}{ RH-5 (R) } \\
\hline In-furrow (0) & $30 \mathrm{~b}$ & $68 \mathrm{a}$ & $71 \mathrm{a}$ & $60 \mathrm{a}$ & $4.0 \mathrm{~b}$ & $47.9 \mathrm{a}$ & $17.6 \mathrm{a}$ & 95.0 & $118 \mathrm{a}$ & $5,652 \mathrm{a}$ \\
\hline Nontreated & $59 \mathrm{a}$ & $72 \mathrm{a}$ & $73 \mathrm{a}$ & $47 \mathrm{~b}$ & $17.4 \mathrm{a}$ & $30.2 \mathrm{~b}$ & $17.1 \mathrm{~b}$ & 94.9 & $114 \mathrm{~b}$ & $3,450 \mathrm{~b}$ \\
\hline HSD $P=0.05$ & 5.4 & 5.6 & 5.6 & 8.5 & 1.98 & 3.90 & 0.36 & 1.02 & 2.8 & 323.7 \\
\hline
\end{tabular}

\footnotetext{
${ }^{\mathrm{t}}$ Population was measured at indicated days after planting (DAP) as the percent stand count of a maximum of 300 plants per $30-\mathrm{m}$ row. $\mathrm{H}=$ percent plant stand at harvest.

"Cultivar and fungicide application timing. $\mathrm{S}=$ susceptible and $\mathrm{R}=$ resistant to Rhizoctonia solani. E-17 and RH-5 were analyzed separately. The rate of application of azoxystrobin for in-furrow (10-cm band) was $0.011 \mathrm{~kg}$ a.i. per 1,000-m row in 94 liters of $\mathrm{H}_{2} \mathrm{O} / \mathrm{ha}$, and the rate for foliar-banded applications (20-cm band) was $0.224 \mathrm{~kg}$ a.i./ha in 233 liters of $\mathrm{H}_{2} \mathrm{O} / \mathrm{ha}$. Number in parentheses indicates DAP. GS = growth stage. GSs were 2 to 4,4 to 6 , and 6 to 8 .

${ }^{v}$ Incidence of plants with signs or symptoms of Rhizoctonia crown and root rot was counted 5 days before harvest (H) over four rows by $90 \mathrm{~m}$ and expressed as the percentage of the potential population (3,600 plants per $360 \mathrm{~m}$ of row).

${ }^{\mathrm{w}}$ Clear juice purity.

${ }^{\mathrm{x}} \mathrm{RWST}=$ recoverable white sucrose per ton and RWSHa $=$ recoverable white sucrose per hectare.

y Values within a column followed by the same letter are not significantly different (Tukey's multiple comparison at $P=0.05$ ).

${ }^{\mathrm{z}} \mathrm{HSD}=$ honestly significant difference.
} 
application but not to any other treatment or the nontreated control $(5,151 \mathrm{~kg})$. The application of azoxystrobin at GS 2 to 4 increased RWSHa in RH-5 compared with the nontreated control and the in-furrow application (Table 6).

\section{DISCUSSION}

$R$. solani AG 2-2 is considered the most serious soilborne pathogen of sugar beet in Michigan and has been the predominant cause of crown and root rot since at least 2001 (W. W. Kirk, unpublished data). R. solani AG 4 was never recovered during the course of this study, even in the smallscale experiments where the pathogen was introduced to plants by artificial inoculation. The isolates of $R$. solani AG 4 used were originally isolated by Hanson (United States Department of Agriculture) in Colorado. Both isolates were found recently to be nonvirulent in seedling pathogenicity tests (J. M. McGrath, personal communications). Therefore, lack of virulence of these isolates may explain why these isolates were never recovered from diseased seedlings.

Disease incidence was greatest in 2004 and least in 2005. Soil moisture, although not specifically examined in this study, was thought to have some role in this observation. The amount of precipitation from 1 April to 30 June in 2005 across mid- and east-central Michigan in the sugar beet growing area was least in 2003 $(167 \mathrm{~mm})$, greatest in $2004(268 \mathrm{~mm})$, and intermediate in 2005 (203 mm). A lack of damage due to Rhizoctonia crown and root rot was a common phenomenon across the Michigan growing region in 2005. The STT $\left(15^{\circ} \mathrm{C}\right)$ was reached sooner in 2004 than in either 2003 or 2005 and all thresholds were reached later in 2003 than in 2004 or 2005. In 2004, when Rhizoctonia crown and root rot was most severe, soils warmed faster than in 2003 or 2005 and there was more precipitation. These observations may indicate that the variables soil temperature and moisture are strongly implicated in incidence and severity of Rhizoctonia crown and root rot in sugar beet in Michigan.

The purpose of this study was to determine whether fungicide applications made early in the season could be improved by timing applications based on crop development or soil temperature criteria. In the small plot trials, early season application of azoxystrobin, either in-furrow, preemergence, or immediately post-emergence, did not affect plant stand. The impact of the early-season application of azoxystrobin in the large-plot trials was sporadic and reduced plant stands sometimes, although the effects generally were transitory. Plant stands may have been reduced by a combination of phytotoxic effects of azoxystrobin and $R$. solani. $(8,10)$, but we could not distinguish between preemergence damping-off and phytotoxicity in this study. Azoxystrobin was generally effective when applied early in the grow- ing season, although pre- or immediate post-emergence applications generally resulted in reduced control of Rhizoctonia crown and root rot relative to the other treatments.

The rate of sugar beet leaf appearance and expansion is in direct response to increasing air temperature (13-15). Soil temperature also increases in direct relation to air temperature, although the effect is buffered with increasing depth in the soil (2). Therefore, it is reasonable to assume that soil temperature and leaf development will increase and progress in tandem. The timing of fungicide applications based on soil temperature was closely related to leaf development stages in all trials where STTs were compared with applications timed based on leaf development stages. No consistent improvement in efficacy of azoxystrobin was observed when applied in accordance with STT compared with achievement of leaf GSs. Under the most severe disease pressure in 2004 , the infurrow and the leaf GS application timings ( 2 to 4,4 to 6 , and 6 to 8 ) all resulted in significantly lower incidence of Rhizoctonia crown and root rot compared with the nontreated control in E-17. The STT of $20^{\circ} \mathrm{C}$ resulted in the latest fungicide application and an incidence of Rhizoctonia crown and root rot not significantly different from the nontreated control.

Many studies have indicated that application of azoxystrobin based on attainment of different GSs can be variable $(3,8,10$,

Table 5. Effect of timing of azoxystrobin application on plant stand, incidence of crown and root rot, yield, and sucrose content in sugar beet exposed to natural inoculum of Rhizoctonia solani AG 2-2 at Linwood, MI, 2004

\begin{tabular}{|c|c|c|c|c|c|c|c|c|c|c|}
\hline \multirow[b]{2}{*}{ Cv. fungicide ${ }^{u}$} & \multicolumn{4}{|c|}{ Population (\%) at DAP ${ }^{t}$} & \multirow[b]{2}{*}{ Incidence $^{v}$} & \multirow[b]{2}{*}{ Yield (t/ha) } & \multirow[b]{2}{*}{ Sucrose $(\%)$} & \multirow[b]{2}{*}{$\operatorname{CJP}(\%)^{\mathrm{w}}$} & \multirow[b]{2}{*}{ RWST $^{\mathrm{x}}$} & \multirow[b]{2}{*}{ RWSHa $(\mathbf{k g})^{\mathrm{x}}$} \\
\hline & 10 & 20 & 30 & $149(\mathrm{H})$ & & & & & & \\
\hline \multicolumn{11}{|l|}{ E-17 (S) } \\
\hline In-furrow (0) & $6 \mathrm{a}^{\mathrm{y}}$ & $49 \mathrm{~b}$ & $78 \mathrm{a}$ & $65 \mathrm{a}$ & $20.1 \mathrm{e}$ & $35.3 \mathrm{a}$ & $18.3 \mathrm{ab}$ & 95.2 & $123 \mathrm{ab}$ & $4,344 \mathrm{a}$ \\
\hline Pre-emergence (3) & $8 \mathrm{a}$ & $47 \mathrm{~b}$ & $74 \mathrm{a}$ & $46 \mathrm{~cd}$ & $34.9 \mathrm{bc}$ & $28.9 \mathrm{ab}$ & $18.3 \mathrm{ab}$ & 95.2 & $123 \mathrm{ab}$ & $3,547 \mathrm{~b}$ \\
\hline At-emergence $(10)$ & $\ldots$ & $\ldots$ & $\ldots$ & $46 \mathrm{~cd}$ & $33.2 \mathrm{bcd}$ & $30.6 \mathrm{ab}$ & $18.2 \mathrm{~b}$ & 95.2 & $122 \mathrm{~b}$ & $3,744 \mathrm{ab}$ \\
\hline GS 2 to $4(20)$ & $\ldots$ & $\ldots$ & $\ldots$ & $56 \mathrm{~b}$ & $27.0 \mathrm{cde}$ & $31.5 \mathrm{ab}$ & $18.1 \mathrm{~b}$ & 95.2 & $122 \mathrm{~b}$ & $3,832 \mathrm{ab}$ \\
\hline GS 4 to $6(30)$ & $\ldots$ & $\ldots$ & $\ldots$ & $53 \mathrm{bc}$ & 26.2 cde & $31.9 \mathrm{ab}$ & $18.6 \mathrm{a}$ & 95.1 & $126 \mathrm{a}$ & $3,997 \mathrm{ab}$ \\
\hline GS 6 to $8(40)$ & $\ldots$ & $\ldots$ & $\ldots$ & $50 \mathrm{bc}$ & $23.5 \mathrm{de}$ & $31.0 \mathrm{ab}$ & $18.6 \mathrm{a}$ & 95.2 & $126 \mathrm{a}$ & $3,909 \mathrm{ab}$ \\
\hline $\mathrm{STT}_{1}(13)$ & $\ldots$ & $\ldots$ & $\ldots$ & $47 \mathrm{~cd}$ & $30.2 \mathrm{~cd}$ & $32.3 \mathrm{ab}$ & $18.1 \mathrm{~b}$ & 95.2 & $122 \mathrm{~b}$ & $3,941 \mathrm{ab}$ \\
\hline $\mathrm{STT}_{2}(35)$ & $\ldots$ & $\ldots$ & $\ldots$ & $54 \mathrm{bc}$ & $29.8 \mathrm{cde}$ & $30.3 \mathrm{ab}$ & $18.2 \mathrm{~b}$ & 95.3 & $123 \mathrm{ab}$ & $3,724 a b$ \\
\hline $\mathrm{STT}_{3}(45)$ & $\ldots$ & $\ldots$ & $\ldots$ & $46 \mathrm{~cd}$ & $41.3 \mathrm{ab}$ & $29.1 \mathrm{ab}$ & $18.3 \mathrm{ab}$ & 95.3 & $123 a b$ & $3,591 \mathrm{~b}$ \\
\hline Nontreated & $11 \mathrm{a}$ & $61 \mathrm{a}$ & $79 \mathrm{a}$ & $40 \mathrm{~d}$ & $44.9 \mathrm{a}$ & $28.4 \mathrm{~b}$ & $18.2 \mathrm{~b}$ & 95.4 & $123 \mathrm{ab}$ & $3,497 \mathrm{~b}$ \\
\hline HSD $P=0.05^{z}$ & 6.0 & 7.6 & 7.0 & 8.0 & 9.71 & 6.44 & 0.35 & 0.62 & 4.0 & 344.2 \\
\hline \multicolumn{11}{|l|}{ RH-5 (R) } \\
\hline In-furrow (0) & $12 \mathrm{a}$ & $49 \mathrm{a}$ & $76 \mathrm{a}$ & $57 \mathrm{a}$ & $1.5 \mathrm{~b}$ & $39.1 \mathrm{a}$ & $18.1 \mathrm{~b}$ & 95.2 & $122 \mathrm{a}$ & $4,758 \mathrm{a}$ \\
\hline GS 2 to $4(20)$ & $\ldots$ & $\ldots$ & $\ldots$ & $51 \mathrm{~b}$ & $1.6 \mathrm{~b}$ & $38.2 \mathrm{a}$ & $18.4 \mathrm{ab}$ & 95.3 & $124 \mathrm{a}$ & $4,748 \mathrm{a}$ \\
\hline Nontreated & $20 \mathrm{a}$ & $51 \mathrm{a}$ & $69 \mathrm{~b}$ & $56 \mathrm{ab}$ & $7.1 \mathrm{a}$ & $37.7 \mathrm{a}$ & $18.6 \mathrm{a}$ & 95.1 & $125 \mathrm{a}$ & $4,725 \mathrm{a}$ \\
\hline HSD $P=0.05$ & 10.0 & 5.6 & 5.7 & 5.2 & 1.05 & 4.56 & 0.35 & 0.29 & 4.8 & 357.1 \\
\hline
\end{tabular}

${ }^{t}$ Population was measured at indicated days after planting (DAP) as the percent stand count of a maximum of 300 plants per 30-m row. $\mathrm{H}=$ percent plant stand at harvest.

" Cultivar and fungicide application timing. $\mathrm{S}=$ susceptible and $\mathrm{R}=$ resistant to Rhizoctonia solani. E-17 and RH-5 were analyzed separately. The rate of application of azoxystrobin for in-furrow (10-cm band) was $0.011 \mathrm{~kg}$ a.i. per 1,000-m row in 94 liters of $\mathrm{H}_{2} \mathrm{O} / \mathrm{ha}$, and the rate for foliar-banded applications (20-cm band) was $0.224 \mathrm{~kg}$ a.i./ha in 233 liters of $\mathrm{H}_{2} \mathrm{O} / \mathrm{ha}$. Number in parentheses indicates DAP. GS = growth stage. GSs were 2 to 4,4 to 6 , and 6 to 8 . $\mathrm{STT}=$ soil temperature threshold, used to generate application timings $\left(\mathrm{STT}_{1}, \mathrm{STT}_{2}\right.$, and $\mathrm{STT}_{3}$ are equivalent to reaching mean daily soil temperatures of 10,15 , and $20^{\circ} \mathrm{C}$, respectively, at $6.0-\mathrm{cm}$ depth).

${ }^{\mathrm{v}}$ Incidence of plants with signs or symptoms of Rhizoctonia crown and root rot was counted 5 days before harvest (H) over 4 rows by $90 \mathrm{~m}$ and expressed as the percentage of the potential population (3,600 plants per $360 \mathrm{~m}$ of row).

${ }^{\mathrm{w}}$ Clear juice purity.

${ }^{\mathrm{x}}$ RWST $=$ recoverable white sucrose per ton and RWSHa $=$ recoverable white sucrose per hectare.

${ }^{y}$ Values within a column followed by the same letter are not significantly different (Tukey's multiple comparison at $P=0.05$ ).

${ }^{\mathrm{z}} \mathrm{HSD}=$ honestly significant difference. 
$11,19)$. Such variability may be linked to differences in timing of environmental conditions conducive to infection and disease development, cultivation techniques, and varietal susceptibility (7). RH-5 was clearly less susceptible to $R$. solani than E-17 throughout the 3 years of the study. In 2005, Buddemeyer and Marlander reported a complex yield response in a comparison of a susceptible and a moderately resistant cultivar to crown and root rot (4). In the absence of $R$. solani, the susceptible cultivar had a $14 \%$ sugar yield increase. In 2007, Buhre et al. reported that the more resistant cultivars in their tests had higher yield potential than the susceptible cultivars (5). Although a similar comparison cannot be made from this study, sugar content was not affected by resistance level; however, the total yield of the more resistant cultivar (RH-5) was greater than that of the susceptible cultivar where the cultivars were exposed to common treatments (untreated control and application of azoxystrobin at GS 2 to 4 ).

Given a knowledge of historical risk of the likely development of crown and root rot at a location, the use of a resistant cultivar without the use of a fungicide would be justified in fields with low risk factors. However, in locations where factors indicate high risk of disease development, the use of a fungicide with a moderately resistant cultivar such as RH-5 would be justified. Because dry seasons cannot be pre- dicted, delaying the application of azoxystrobin until GS 4 to 6 would be justified because, generally, the infective period is early in the season $(3,6,18)$, prior to canopy closure. In 2005, in this study, little disease developed and, in such a season, no fungicide would have been necessary on either cultivar. Therefore, application would be justified only in years when wet conditions prevailed up to at least GS 4 to 6 . Further systematic work on soil moisture conditions that enhanced risk factors for crown and root rot would be required to make specific recommendations for justification of fungicide applications.

The overall effect of the fungicide application at GS 2 to 4 was a reduction in crown and root rot severity in both cultivars but the effect was enhanced in the susceptible cultivar. Where application rates and split applications were compared, there was no clear advantage to using the increased rate of fungicide or the split application strategy, although this was only evaluated in 2003. The effect of application timing of azoxystrobin on RWSHa was directly on yield, but RWST, sucrose content, and CJP were rarely affected. In 2003, when Rhizoctonia crown and root rot was severe, the in-furrow application resulted in greatest RWSHa in both E-17 and RH-5. In 2004, the effect was observed only in E-17. In the absence of significant disease pressure in 2005, there was no effect of application timing of azoxystrobin on RWSHa although, in RH5 , elevated RWSHa was observed in the application at GS 2 to 4 compared with the in-furrow application.

In our studies, timing applications of azoxystrobin with respect to attainment of specific soil temperatures did not improve efficacy on Rhizoctonia crown and root rot over timing of application based on leaf stage alone. Sugar beet is planted in flat fields in Michigan and current sugar beet agricultural practices in Michigan involve mechanical cultivation during the period when plants are in GS 2 to 4 through 6 to 8. This practice may deposit infested soil in the crown of developing plants. The timing of application of azoxystrobin may be most effective if applied just before this cultivation event. However, in this study, the clear efficacy of the in-furrow applications and the reduced efficacy of the preemergence applications refute this argument. The mechanism by which protection is afforded by azoxystrobin to immature sugar beet plants remains unclear (10) but may be a direct effect on primary inoculum in the soil, protection of immature seedlings and leaves, or a combination of the two.

\section{ACKNOWLEDGMENTS}

This work was funded by Michigan Sugar Beet Advancement and Michigan State University (Project GREEEN). We thank P. Horney, Michigan State University Bean and Beet Farm; Meylan Farms; and V. Lengkeek (Syngenta) for critically reviewing this manuscript.

Table 6. Effect of timing of azoxystrobin application on plant stand, incidence of crown and root rot, yield, and sucrose content in sugar beet exposed to natural inoculum of Rhizoctonia solani AG 2-2 at Linwood, MI, 2005

\begin{tabular}{|c|c|c|c|c|c|c|c|c|c|c|}
\hline \multirow[b]{2}{*}{ Cv., fungicide ${ }^{u}$} & \multicolumn{4}{|c|}{ Population (\%) at DAP ${ }^{t}$} & \multirow[b]{2}{*}{ Incidence $^{\mathrm{v}}$} & \multirow[b]{2}{*}{ Yield (t/ha) } & \multirow[b]{2}{*}{ Sucrose $(\%)$} & \multirow[b]{2}{*}{$\operatorname{CJP}(\%)^{\mathrm{w}}$} & \multirow[b]{2}{*}{ RWST $(\mathbf{k g})^{\mathrm{x}}$} & \multirow[b]{2}{*}{ RWSHa $(\mathbf{k g})^{\mathrm{x}}$} \\
\hline & 21 & 31 & 40 & $138(H)$ & & & & & & \\
\hline \multicolumn{11}{|l|}{ E-17 (S) } \\
\hline In-furrow (0) & $11 \mathrm{~b}^{\mathrm{y}}$ & $40 \mathrm{~b}$ & $47 \mathrm{~b}$ & $48 \mathrm{c}$ & $0.2 \mathrm{~d}$ & $49.7 \mathrm{a}$ & $16.4 \mathrm{a}$ & 92.9 & $104 \mathrm{a}$ & $5,168 \mathrm{abc}$ \\
\hline Pre-emergence (3) & $19 \mathrm{a}$ & $49 \mathrm{a}$ & $56 \mathrm{a}$ & $53 a b c$ & $1.3 \mathrm{~b}$ & $48.6 \mathrm{a}$ & $16.5 \mathrm{a}$ & 93.5 & $106 \mathrm{a}$ & $5,151 \mathrm{abc}$ \\
\hline At-emergence (11) & $\ldots$ & $\ldots$ & $\ldots$ & $57 \mathrm{a}$ & $1.1 \mathrm{bc}$ & $48.4 \mathrm{a}$ & $16.1 \mathrm{a}$ & 93.3 & $103 \mathrm{a}$ & $4,985 \mathrm{c}$ \\
\hline GS 2 to $4(21)$ & $\ldots$ & $\ldots$ & $\ldots$ & $55 \mathrm{ab}$ & $1.2 \mathrm{~b}$ & $48.0 \mathrm{a}$ & $16.5 \mathrm{a}$ & 93.4 & $106 \mathrm{a}$ & $5,088 \mathrm{bc}$ \\
\hline GS 4 to $6(31)$ & $\ldots$ & $\ldots$ & $\ldots$ & $55 \mathrm{ab}$ & $1.0 \mathrm{bc}$ & $51.6 \mathrm{a}$ & $16.3 \mathrm{a}$ & 93.4 & $104 \mathrm{a}$ & $5,366 \mathrm{ab}$ \\
\hline GS 6 to 8 (42) & $\ldots$ & $\ldots$ & $\ldots$ & $55 \mathrm{ab}$ & $0.9 \mathrm{c}$ & $50.6 \mathrm{a}$ & $16.7 \mathrm{a}$ & 93.4 & $108 \mathrm{a}$ & $5,464 \mathrm{a}$ \\
\hline $\mathrm{STT}_{1}(16)$ & $\ldots$ & $\ldots$ & $\ldots$ & $47 \mathrm{c}$ & $1.1 \mathrm{~b}$ & $50.1 \mathrm{a}$ & $16.2 \mathrm{a}$ & 93.1 & $103 \mathrm{a}$ & $5,160 a b c$ \\
\hline $\mathrm{STT}_{2}(25)$ & $\ldots$ & $\ldots$ & $\ldots$ & $50 \mathrm{bc}$ & $1.7 \mathrm{a}$ & $48.3 \mathrm{a}$ & $16.4 \mathrm{a}$ & 92.8 & $104 \mathrm{a}$ & $5,023 \mathrm{bc}$ \\
\hline $\mathrm{STT}_{3}(57)$ & $\ldots$ & $\ldots$ & $\ldots$ & $55 \mathrm{ab}$ & $0.4 \mathrm{~d}$ & $52.0 \mathrm{a}$ & $16.6 \mathrm{a}$ & 93.2 & $106 \mathrm{a}$ & $5,512 \mathrm{a}$ \\
\hline Nontreated & $21 \mathrm{a}$ & $53 \mathrm{a}$ & $57 \mathrm{a}$ & $56 \mathrm{ab}$ & $1.8 \mathrm{a}$ & $48.6 \mathrm{a}$ & $16.5 \mathrm{a}$ & 93.4 & $106 \mathrm{a}$ & $5,151 \mathrm{abc}$ \\
\hline HSD $P=0.05^{z}$ & 4.7 & 8.1 & 3.8 & 6.1 & 0.25 & 10.93 & 0.71 & 2.69 & 5.7 & 365.4 \\
\hline \multicolumn{11}{|l|}{ RH-5 (R) } \\
\hline In-furrow & $22 \mathrm{~b}$ & $53 \mathrm{~b}$ & $56 \mathrm{~b}$ & $57 \mathrm{~b}$ & $0.26 \mathrm{a}$ & $49.2 \mathrm{a}$ & $15.3 \mathrm{~b}$ & 93.8 & $99 \mathrm{~b}$ & $4,870 \mathrm{~b}$ \\
\hline GS 2 to $4(21)$ & $\ldots$ & $\ldots$ & $\ldots$ & $59 \mathrm{ab}$ & $0.46 \mathrm{a}$ & $52.7 \mathrm{a}$ & $16.1 \mathrm{a}$ & 93.5 & $104 \mathrm{a}$ & 5,480 a \\
\hline Nontreated & $33 \mathrm{a}$ & $62 \mathrm{a}$ & $66 \mathrm{a}$ & $64 \mathrm{a}$ & $0.44 \mathrm{a}$ & $50.5 \mathrm{a}$ & $15.4 \mathrm{~b}$ & 94.1 & $100 \mathrm{~b}$ & $5,050 \mathrm{~b}$ \\
\hline HSD $P=0.05$ & 8.1 & 4.5 & 4.0 & 6.5 & 0.31 & 5.08 & 0.26 & 1.20 & 3.2 & 384.8 \\
\hline
\end{tabular}

${ }^{t}$ Population was measured at indicated days after planting (DAP) as the percent stand count of a maximum of 300 plants per 30-m row. $\mathrm{H}=$ percent plant stand at harvest.

${ }^{u}$ Cultivar and fungicide application timing. $\mathrm{S}=$ susceptible and $\mathrm{R}=$ resistant to Rhizoctonia solani. E-17 and RH-5 were analyzed separately. The rate of application of azoxystrobin for in-furrow (10-cm band) was $0.011 \mathrm{~kg}$ a.i. per 1,000-m row in 94 liters of $\mathrm{H}_{2} \mathrm{O} / \mathrm{ha}$, and the rate for foliar-banded applications (20-cm band) was $0.224 \mathrm{~kg}$ a.i./ha in 233 liters of $\mathrm{H}_{2} \mathrm{O} / \mathrm{ha}$. Number in parentheses indicates DAP. GS = growth stage. GSs were 2 to 4,4 to 6 , and 6 to 8 . $\mathrm{STT}=$ soil temperature threshold, used to generate application timings $\left(\mathrm{STT}_{1}, \mathrm{STT}_{2}\right.$, and $\mathrm{STT}_{3}$ are equivalent to reaching mean daily soil temperatures of 10,15 , and $20^{\circ} \mathrm{C}$, respectively, at 6.0 -cm depth).

${ }^{\mathrm{v}}$ Incidence of plants with signs or symptoms of Rhizoctonia crown and root rot was counted 5 days before harvest (H) over 4 rows by $90 \mathrm{~m}$ and expressed as the percentage of the potential population (3,600 plants per $360 \mathrm{~m}$ of row).

${ }^{\mathrm{w}}$ Clear juice purity.

${ }^{\mathrm{x}} \mathrm{RWST}=$ recoverable white sucrose per ton and RWSHa $=$ recoverable white sucrose per hectare.

y Values within a column followed by the same letter are not significantly different (Tukey's multiple comparison at $P=0.05$ ).

${ }^{\mathrm{z}} \mathrm{HSD}=$ honestly significant difference. 


\section{LITERATURE CITED}

1. Baker, R., and Martinson, C. A. 1970. Epidemiology of diseases caused by Rhizoctonia solani. In: Rhizoctonia solani: Biology and Pathology. J. R. Parmeter, Jr., ed. University of California Press, Berkeley.

2. Bartlett, M. G., Chapman, D. S., and Harris, R. N. 2006. A decade of ground-air temperature tracking at Emigrant Pass Observatory, Utah. J. Clim. 19:3722-3731.

3. Brantner, J. R., and Windels, C. E. 1999. Infurrow and postemergence application of Quadris for control of Rhizoctonia dampingoff and root and crown rot. Sugar Beet Res. Ext. Rep. 29:275-277.

4. Buddemeyer, J., and Marlander B. 2005. Genotypic reaction of sugar beet to Rhizoctonia solani root and crown rot-susceptibility, yield and (quality at different levels of infestation). J. Plant Dis. Prot. 112:105-117.

5. Buhre, C., Wagner, G., Kluth, S., Kluth, C., Apfelbeck, R., and Varrelmann, M. 2007. Resistance of sugarbeet varieties as basis for the integrated control of root and crown rot (Rhizoctonia solani). Zuckerindustrie 132:5055 .

6. Buttner, G., Ithurrart, M. E. F., and Buddemeyer, J. 2002. Root and crown rot Rhizoctonia solani-distribution, economic importance and concepts of integrated control. Zuckerin- dustrie 127:856-866.

7. Engelkes, C. A., and Windels, C. E. 1994. Relationship of plant-age, variety, and isolate of Rhizoctonia solani AG2-2 to sugar-beet root and crown rot. Plant Dis. 78:685-689.

8. Jacobsen, B. J., Bergman, J., and Eckhoff, J. 1999. Control of Rhizoctonia crown and root rot of sugar beet with fungicides and antagonistic bacteria. Sugar Beet Res. Ext. Rep. 29:278-280.

9. Karaoglanidis, G. S., and Karadimos. D. A. 2006. Efficacy of strobilurins and mixtures with DMI fungicides in controlling powdery mildew in field-grown sugar beet. Crop Prot. 25:977-983.

10. Kiewnick, S., Jacobsen, B. J., BraunKiewnick, A., Eckhoff, J. L. A., and Bergman, J. W. 2001. Integrated control of Rhizoctonia crown and root rot of sugar beet with fungicides and antagonistic bacteria. Plant Dis. 857:718-722.

11. Kirk, W. W., Schafer, R. L., Berry, D., and Wharton, P. S. 2007. Control of crown and root rot in sugar beet with fungicides, Michigan, 2005. PDMR 1:FC054.

12. Ko, W., and Hora, F. K. 1971. A selective medium for the quantitative determination of Rhizoctonia solani in the soil. Phytopathology 61:707-710.

13. Milford, G. F. J, Pocock, T. O., and Riley, J.
1985. An analysis of leaf growth in sugar beet. I. Leaf appearance and expansion in relation to temperature under controlled conditions. Ann. Appl. Biol. 106:163-172.

14. Milford, G. F. J, Pocock, T. O., and Riley, J. 1985. An analysis of leaf growth in sugar beet. I. Leaf appearance in field crops. Ann. Appl. Biol. 106:173-185.

15. Milford, G. F. J, Pocock, T. O., and Riley, J. 1985. An analysis of leaf growth in sugar beet III. Leaf expansion in field crops. Ann. Appl. Biol. 106:187-203.

16. Rush, C. M., and Winter, S. R. 1990. Influence of previous crops on Rhizoctonia root and crown rot of sugar-beet. Plant Dis. $74: 421-425$.

17. Salazar, O., Julian, M. C., and Rubio, V. 2000. Primers based on specific rDNA-ITS sequences for PCR detection of Rhizoctonia solani, $R$. solani AG 2 subgroups and ecologica types, and binucleate Rhizoctonia. Mycol. Res. 104:281-285

18. Whitney, E. D., and Duffus, J. E. 1986. Compendium of Beet Diseases and Insects, 3rd ed American Phytopathological Society Press, St Paul, MN.

19. Windels, C. E., and Brantner, J. R. 2000. Band and broadcast-applied Quadris for control of Rhizoctonia on sugar beet. Sugar Beet Res. Ext. Rep. 30:266-270. 